\title{
A CENTURY OF UNEVEN AND COMBINED DEVELOPMENT: THE EROSION OF UNITED STATES HEGEMONY AND THE RISE OF CHINA
}

Michael Dunford, Liu Weidong

Institute of Geographical Sciences and Natural Resources Research, Chinese Academy of Sciences

The concept of uneven and combined development where the interconnectedness and interactions of different societies shape and combine with their internal structures to drive the evolution of comparative development and power is used to examine the drivers of successive phase of global development in the 100 years since 1917. This concept was coined by left-wing theorist and the Soviet Communist party leader Leo Trotsky with the aim of explaining peculiarities of imperial Russia's development. Currently it is applied for different cases of political and economic development on the global level. The concept of uneven and combined development allows taking into account both intra-state and extra-state factors, including political regimes evolution, international trade dynamics.

Most attention is paid to the drivers of secular economic decline in the United States and the Western world, the way it was tempered by a wave of productive and financial globalization that itself permitted the rise of a number of emerging economies with the economic, political and cultural capacity to exploit latecomer advantage and the way the rise of new powers is leading in the direction of a polycentric multi-civilizational world and a possibly more inclusive model of development. The article addresses political economy of global power shifts and their prospects.

Key words: uneven and combined development, the United States, China, real and financial globalization. 
$\mathrm{I}$ $\mathrm{n}$ the last 100 years several fundamental power shifts have occurred. Of these evolutions this article aims to deal with two: (1) the rise and especially the decline of United States (US) hegemony and of the unipolar world established after the collapse of Communism in Eastern Europe and the former Soviet Union; and (2) the current power shift to Eurasia and the global East (Russia, Brazil, South Africa, Indonesia, India, Iran and in particular China) and the re-emergence of a multipolar world respecting civilizational variety. These shifts have important inter-related cultural, political and military dimensions: the recent militarization of US foreign policy, erosion of US soft power and diplomatic authority and restoration of Russian military capability all play important roles. The aim of this article is however to identify domestic and external macro-economic mechanisms underlying these power shifts drawing on the Trotsky's concept of uneven and combined development.

More specifically the argument is that the erosion of US dominance resides in an ineffective and ultimately counter-productive response to the 1970s' economic crisis. Not only did this neo-liberal response fail to restore US economic growth but paradoxically it created conditions favoring the emergence of those contender states whose capacity to exploit latecomer advantage drove rapid economic growth and whose growth eroded the ability of the US to appropriate value from the rest of the world. At the same time it is argued that differential capacities of adaptation and adjustment arise from differences in social models and governance capacity. In this article attention is paid to three social models: the post-war western Golden Age, the post-1970s' neo-liberal Anglo-American model and the evolving Chinese social model.

These power shifts are an increasing focus of attention. In The Rise and Fall of the Great Powers Kennedy anticipated relative US decline due to uneven rates of growth and technological and organizational innovation [28]. More recently structural US decline and the rise of China was examined through the lens of world history. Amongst the most striking is Arrighi's Adam Smith in Beijing [5]. In this volume Arrighi draws inspiration from Frank's attempt in ReOrient [15] to overcome Eurocentrism through an examination of world history from 1400 to 1800, draws on Adam Smith, Karl Marx, Joseph Schumpeter, Fernand Braudel and Hannah Arendt, engages in debates with Harvey [22], Brenner [7] and others and relies on a world systems approach. Arrighi argues that the US and its associated capitalist model of development has undergone a transition from a signal to a terminal crisis of hegemony in the face of the rise of an alternative model of development that he calls, after Adam Smith, market society and suggests that this shift prefigures the arrival of a Commonwealth of civilizations. This optimistic scenario is one for which one must hope, while the idea that China is noncapitalist market society is one that contains significant elements of truth although it seriously underplays the results of the interaction of China with global capitalism.

Also from a world systems perspective Grinin and Korotayev [17] see the rise of the West and the current phase of convergence as one in a sequence of phases of convergence and divergence associated with innovation and inventiveness driven geographies of relative dynamism and stagnation. The main significance of this volume is the 
account of the spread of technologies and the suggestion that the relative dynamism of Europe dates from the late fifteenth century and involved inter-regional interaction. The switch from divergence to convergence is said to coincide with the information technology revolution although latecomer catch-up started earlier. Although technology is a driver of change, this important evidence identifies something that has itself to be explained.

In this article the aim is to suggest an alternative approach that draws on theories of regulation [2;11], the concept of varieties of capitalism and, especially, the concept of uneven and combined development (U\&CD). The significance of U\&CD is that, in a world in which a multiplicity of unequally developed states coexist, it combines internal (domestic or unit-level) and external (international, system-level or inter-societal) phenomena and drivers to provide an explanation of the actions and outcomes arising from these structures $[45 ; 46 ; 51 ; 52]$. Theories of regulation while examining cycles of economic growth and their punctuation by economic crises differs from for example the study of Kondratieff cycles $[6 ; 18 ; 33]$ in that it involves analysis of the joint transformation of economic structures and institutional arrangements [3] and the political and economic drivers of capital accumulation. As Zhu [54] emphasizes, one of the important features of the current power shift is the end of the third wave of democracy [25] and the evident crisis of western multi-party representative politics. In this respect the study of varieties of capitalism $[14 ; 19]$ moves in the direction of an analytical interpretation of societal variety and institutional performance.

As already indicated, the last one hundred years a series of dramatic restructurings involving uneven and combined processes of industrialization and urbanization and changes in political and military power saw a number of European countries and areas settled by Europeans first pull away from the rest of the world and then slowly lose their positions of dominance as other countries started to catch-up but at different speeds. One hundred years ago the US emerged from the First World War unscathed and in a particularly strong international position. In Russia the Bolshevik Revolution saw the establishment of socialism and the Soviet Union. The 1919 Treaty of Versailles agreed by the victorious powers imposed damaging reparations on Germany. As its hegemonic role declined, Great Britain sought to return to the status quo ex ante by tying the international exchange value of sterling to gold at the 1914 rate. This decision damaged British economic competitiveness [29]. The aim however was to stabilize conditions for international trade and investment, which had increased dramatically in the phase of industrialization, imperial rivalry and globalization up to the First World War (Figure 1), and preserve the role of sterling and Britain's imperial reach. In 1931 massive outflows of gold put downward pressure on Britain's exchange rate and forced the abandonment of the gold parity as the first of three major economic crises, which have punctuated the last 100 years of capitalist development, unfolded.

The crisis of economic liberalism that erupted in 1929 saw core country output and employment collapse, reinforcing protectionism and downturns in international trade and capital mobility. Three main ways forward emerged: a socialist planned 
economy model of rapid catch-up industrialization in the Soviet Union; the mobilization of national cultural communities to regulate yet preserve private economic power in countries that turned to corporatism and Fascism; and social democracy with the rise of Keynesianism and New Deal politics in North America and Western Europe. The struggles between these three pathways and between new and old rising powers was settled with the defeat of Fascism and of Germany and Japan in the Second World War and the division of the world into a Socialist bloc centered on the Soviet Union and China, and a more economically advanced western bloc in which the US emerged as the new hegemonic power.

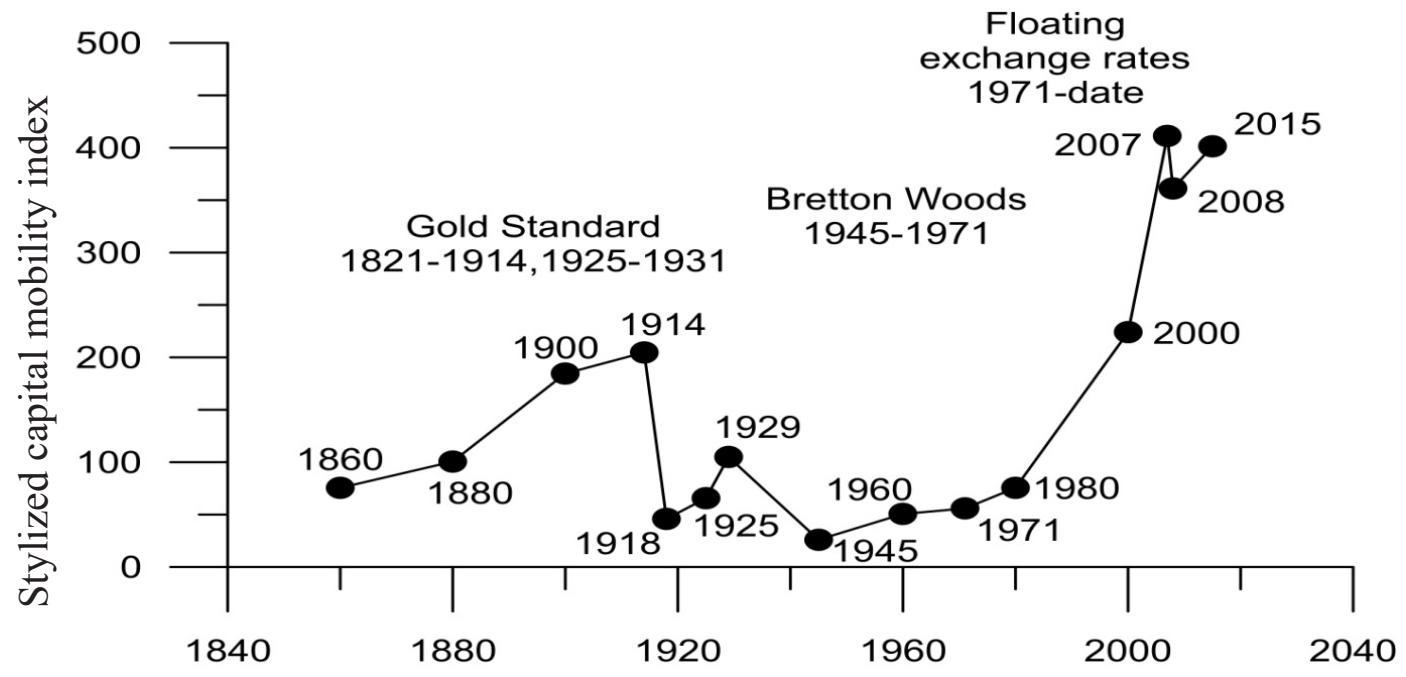

Fig. 1. Globalization ebbs and flows ${ }^{1}$

At the end of the Second World War, the US accounted for nearly two-thirds of world industrial output [23, p. 258], and had the world's most productive industrial capacity and largest financial reserves, allowing it to set the agenda and determine the outcome of the July 1944 Bretton Woods Conference that established a new international financial and trade system. Although the US aim was a global open door policy granting US economic interests access to markets and resources on their terms throughout the world, a complex system of co-operation and rivalry nonetheless saw other countries draw on their relative strengths to map out roles in a US dominated western order. Great Britain for example continued to play a role as a major global financial centre despite the undermining of its system of imperial preference, the decline in the role of sterling and relative economic decline. At the same time domestic reform profoundly shaped by the challenge of Communism saw the establishment of mixed economies. Characterized by the establishment of the primacy of industrial over financial capital, a combination of mass production and mass consumption (Taylorism

\footnotetext{
1 Based on Obstfeld and Taylor [42] as well as data from Bank for International Settlements // Bank for International Settlements. 2017. Locational banking. Bank for International Settlements. URL: http://www.bis.org/statistics/bankstats. htm?m=6\%7С31\%7C69 (дата обращения: 01.10.2017).
} 
and Fordism), significant public ownership, welfare states and Keynesian economic management, this 'great transformation' [43] opened the way to a thirty-year Golden Age of relatively rapid economic growth, full employment and declining inequality. At the same time the US came to occupy the centre of an open international system in which international trade and investment slowly increased (Figure 1) and in which the war-torn economies of Western Europe and Japan embarked on rapid catch-up industrialization. Although catch-up industrialization subsequently spread to the four Asian Tigers, in the 1970s this era came to an end, opening the way to the progressively slower growth of advanced capitalist economies.

Without the external assistance provided by the US to Western Europe and East Asia, the recovery of the devastated economies of socialist Eastern Europe was also remarkably rapid, while China initially with Soviet support started to lift itself from its position as the poorest economy in the world in 1949. As the growth of planned economies slowed, in 1989-91 the societies of Central and Eastern Europe and the Former Soviet Union embarked on a series of transitions involving the replacement of the political rule by their Communist parties by representative democracies and their command economies by capitalist (and not simply market) economic systems. Associated with these domestic transitions was an integration of the former Communist world into a new international economic and political order characterized by the increasing influence of a number of global institutions, closely dependent on the USA, and a subdivision of the developed world into a small number of powerful, complementary yet competing economic blocs in North America, Europe and East Asia.

China however adopted a different path also involving the joint transformation of economic structures and public institutions. In 1978 the Third Plenary Session of the Eleventh Central Committee of the Communist Party of China (CPC) confirmed the decision to embark on reform and opening up (găigé kāifàng), reforming the planned economy and constructing a socialist market economy with Chinese characteristics. The aim was to make China a unified and modern economic power capable of catching up with and overtaking the western world, and of raising the living standards of the population, while preserving the integrity of the country and leading role of the CPC. Coinciding with years of economic crisis in the western world that saw globalization accelerate as industries were offshored to restore profitability by exploiting the cheap labor of emerging countries, China grew at an average of close to 10 per cent per year for nearly thirty years, emerging as the second largest economy in the world, the manufacturing workshop of the world and eventually a major capital exporter.

China's ascent was remarkably anticipated by Hobson [24] in his study of imperialism in which he wrote: "In our dealings with backward races capable of instruction in Western industrial methods there are three stages. First comes ordinary commerce ... Next, after Great Britain, or some other Western Power has acquired territory or invested capital in the foreign country with the aim of developing the resources, she enjoys a period of large export trade ... not necessarily balanced by the import trade since it really covers the process of investment. ... But a third stage remains, one 
which in China at any rate may be reached at no distant period, when capital and organizing energy may be developed within the country ... Thus fully equipped for future internal development in all the necessary productive powers, such a nation may turn upon her civiliser, untrammeled by need of further industrial aid, undersell him in his own market, take away his other foreign markets and secure for herself what further developing work remains to be done in other undeveloped parts of the earth".

Major subsequent geoeconomic and geopolitical trends indicate that Hobson's prediction showed remarkable foresight. However these trends also reflect the insights of other writers of that epoch including Trotsky's concept of U\&CD. This concept will be discussed briefly in the next section [13], after which attention will be paid to the relative decline of the US and the rise of China. The final section will conclude.

\section{Uneven and combined development}

As just mentioned, the relative decline of western powers, the rise of emerging powers and the consequent re-emergence of a polycentric world can be understood in the light of Trotsky's theory of U\&CD, while the possibility of China actually overtaking western countries was remarkably anticipated by Hobson [24].

The concept/law of U\&CD was introduced by Trotsky [51; 52] to explain the 'peculiarities' of the economic, political and cultural development of Russia before the 1917 Bolshevik revolution. For Trotsky economic backwardness was an expression of the law of unevenness, which he later argued governed the whole history of mankind, explaining 'the extreme diversity in the levels attained, and the extraordinary unevenness in the rate of development of the different sections of mankind during the various epochs' [51].

Trotsky argued however that there is a related law of combined development. 'Capitalism finds various sections of mankind at different stages of development, each with its profound internal contradictions. ... In contrast to the economic systems which preceded it, capitalism inherently and constantly aims at economic expansion ... and equalizes the economic and cultural levels of the most progressive and the most backward countries'. Backward countries were compelled to follow after advanced countries ('the whip of external necessity'), but do not 'take things in the same order. The privilege of historic backwardness ... compels the adoption of whatever is ready in advance of any specified date, skipping a whole series of intermediate stages'. The outcome of this dialectic of compulsion and privilege was 'the drawing together of different stages of the journey, a combination of the separate steps, an amalgam of archaic with contemporary forms' [51].

The most striking recent recovery of the concept of U\&CD has occurred in the field of international relations where it serves to draw attention to the causal role of state actions and inter-state relations and counters the exaggerations of 1990s theories of globalization which suggested that increasing interconnectedness was leading to the replacement of the sovereign state system by a multi-layered, multilateral system of 
'global governance'. In the words of Rosenberg: 'all societies coexist with and interact with others, and ... this [interaction] super-adds a lateral field of causality over and above the 'domestic' determinations arising from each and every one of the participant societies [9, p. 88]: the development of individual societies not in their internal structures and agents alone but also in their interconnectedness with other societies.

For Trotsky, combined 'grows out of the first [uneven development] and completes it' [10, p. 295]. In a world of unequally developed polities interactive relations with other developmentally differentiated societies are sources of constraint and creativity. Countries that are less developed are enmeshed in asymmetric webs of economic, political and military dependence that can impede/enhance their growth and development. At the same time depending on economic and cultural capacities of adaptation and assimilation, state domestic and international governance capacity, underlying social relationships/capabilities $[1 ; 52]$ contender countries can also draw on the advantage of backwardness to appropriate what is relatively advanced (through investment, learning and acquisition), avoid steps on the path (through stage skipping investment), create combinations with a higher preponderance of modern elements and generate these effects quickly and strongly.

Material and non-material aspects of modernity derived from more advanced societies are grafted on and combined, in the absence of the social relations from which they emerged, with internal social relations to produce and reproduce in ever-changing forms 'amalgamated socio-political institutions, socio-economic systems, ideologies and material practices' $[4, \mathrm{p} .45]$ which in turn react upon more developed societies [38]. The encounter of capitalism with pre-existing and non-capitalist forms of work and life gives rise a unique, heterogeneous and constantly reconfigured mixture of 'native' and 'foreign', 'advanced' and 'backward', 'new' and 'old', 'modern' and 'traditional' economic, political and cultural forms. As José Carlos Mariátegui indicated, the result is the rendition of contemporaneous non-contemporaneity or synchronous non-synchronicity 'into a palimpsest-like paradigm' of social change [21, p. 4]. These combinations make development outcomes interactive, multiple and contingent.

\section{The decline of US hegemony}

The theory of $U \& C D$ combines the analysis of the rise and decline of nations and the rise and decline of institutions [53] requiring an identification of the institutionally contingent economic mechanisms and the political structures and interactions that increase and reduce unevenness. Trotsky explicitly identified the culturally contingent role of latecomer advantage in eroding the lead of economically and politically advanced societies. The mirror image of the privilege of backwardness is the handicap of a head start. A head start is a source of economic and political advantages yet can also give rise to rigidities that impede progress if, for example, accumulation slows and the scrapping of old and investment in new assets are restricted. 


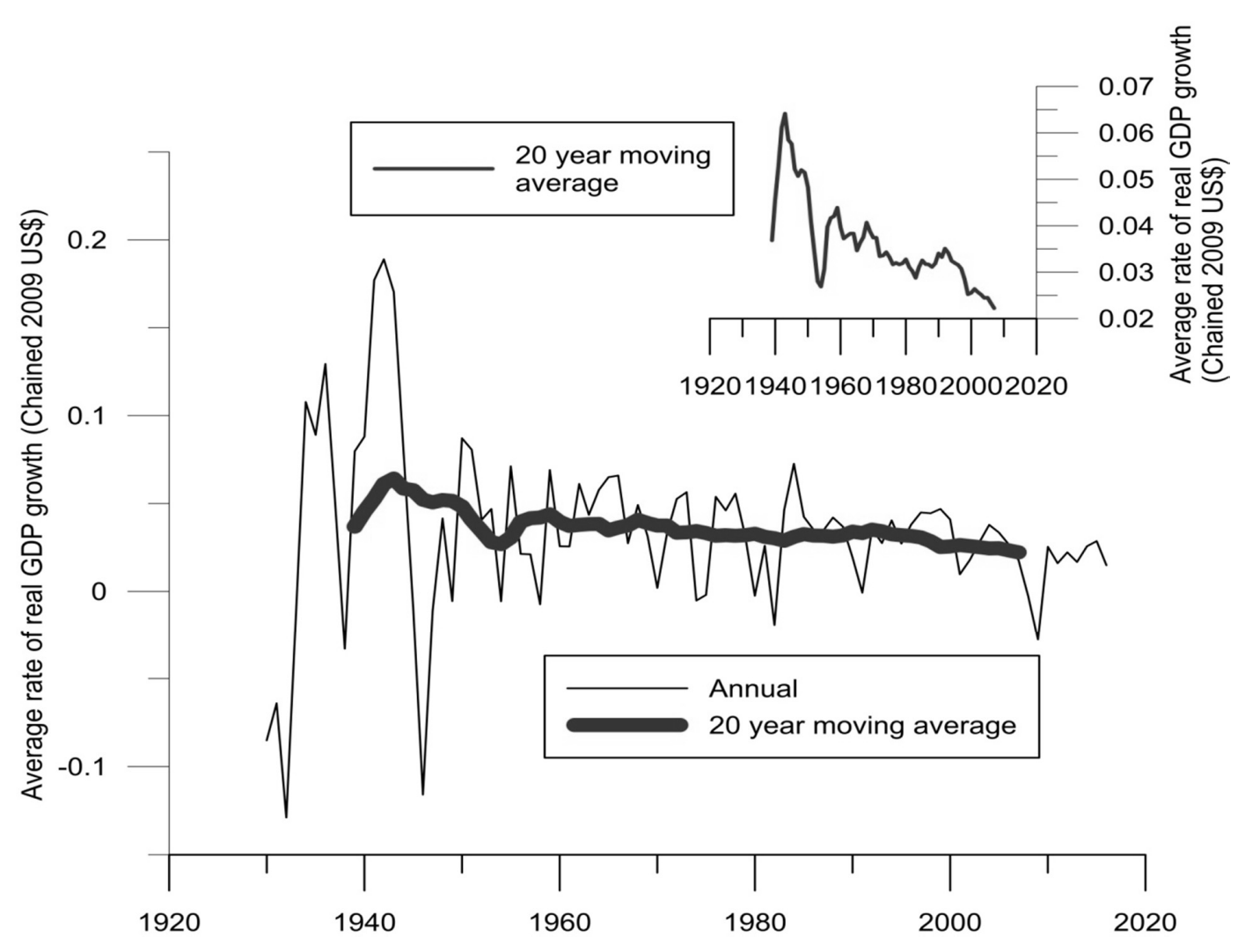

Fig. 2. US real GDP growth, 1929-2016²

All advanced economies have seen growth rates progressively decline and fall behind those of some emerging powers. In the case of the US, the peak values of 20-year moving average annual rates of Gross Domestic Product (GDP) growth declined from $6.4 \%$ in 1943 to $4.4 \%$ in $1958,4.1 \%$ in $1968,3.5 \%$ in 1992 and $2.6 \%$ in 2001 . This slowdown is a result in part of declining productivity growth (except for a short surge in the second half of the 1990s) dating in the US case from 1970, although this problem plagues all G7 countries including latecomers such as Japan. Notwithstanding the development of artificial intelligence, robotics and genetic engineering, this slowdown is expected to continue. Gordon [16] for example argues that the economy-wide transformative impact of recent innovations is smaller than those of the late nineteenth and first three quarters of the twentieth century. The impact of digital technologies was much smaller, while the impact of current-day new technologies (genomics and genetic engineering, nanotechnologies, robotics and artificial intelligence) is restricted by four 'headwinds' (demography, education, inequality and debt) meaning that the US faces lower growth for the next 25 to 40 years. Compared, moreover, with countries which are not yet at the current technological frontier, and which can therefore adopt

\footnotetext{
2 Based on data of Bureau of Economic Analysis // Bureau of Economic Analysis, U. D. o. C. 2017. US economic accounts. URL: https://bea.gov/ (accessed: 01.10.2017).
} 
existing technologies and skip steps along the path, the scope for growth in the US and other developed countries is much more limited.

What drives growth however is not so much innovation as capital accumulation and the replication of investments that lead to their diffusion. These waves of capital accumulation start with the emergence and initial diffusion of technologies and products and proceed, sometimes through crises of adaptation, to their maturity. Capital accumulation and the renewal of the capital stock depend however on investment and savings, which have declined as a share of GDP, and in a capitalist society on profitability, which has also declined.

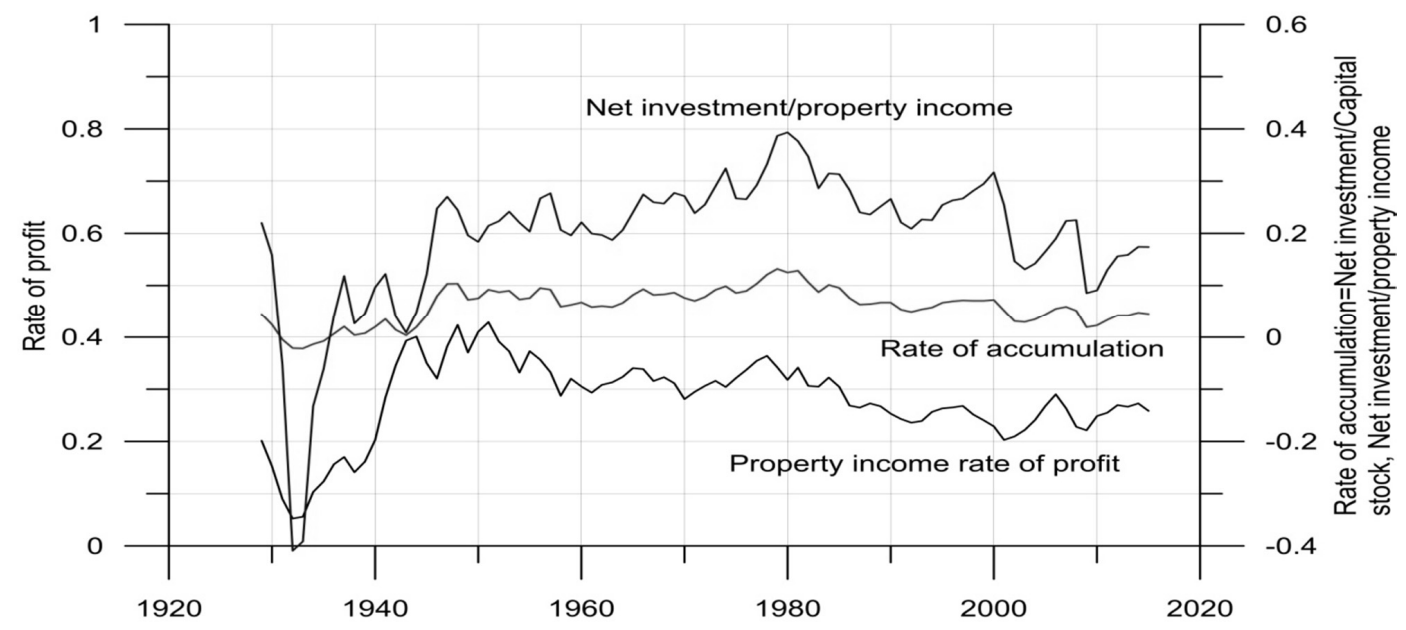

Fig. 3. US corporate profitability and investment, 1929-2016

As Figure 3 shows rates of profit in the US were high in the immediate postwar years. In the 1950s the consequence was high rates of investment in new technologies including electric-powered machine tools, assembly-line production, aviation, white goods, air-conditioning, inter-state highways, petro-chemicals, supermarkets and television sets employing an abundant supply of labour and using cheap raw materials in a context of Keynesian macro-economic management and industrial policy. These high rates of investment and capital accumulation drove rapid economic growth and a radical transformation of ways of life ${ }^{3}$.

This Golden Age did not last, as US financial and non-financial corporations eventually faced a declining rate of profit from the mid-1960s (Figure 3), entering a classic period of crisis from which it has essentially not recovered. In the 1980s declining profitability and growth were temporarily reversed as a result of an increase in the efficiency of capital, a change in corporate management and an increase in the share of financial sector, spurred by Anglo-American financial liberalization and deregulation. With the emergence in the 1980s of private equity in the shape of leveraged buyouts, and with an increase in the equity holdings in listed companies in the hands of

\footnotetext{
3 This rate of profit is computed at historical cost [32]. The property income rate includes taxes and interest payments. The detailed trajectory of a rate of profit computed at current cost differs but the overall trend is downwards.
} 
financial investors and wealthy individuals along with increased cross-shareholdings of non-financial companies, equity market value and shareholder value (instead of stakeholder value) emerged as the main measure of firm performance 'decoupling financial yield and the economic return on capital, decoupling median wage growth and productivity gains, and decoupling after-tax and primary income' [3]. As productive investment in developed countries remained unattractive, the share of the financial sector in US profits increased sharply (Figure 4) , $^{4}$ as did the gap between the market value for the ownership securities of US enterprises and the market value of the capital assets employed ${ }^{5}$. Once the decline in profitability set in again, exacerbated by high levels of outstanding debt, investment declined, and growth came to depend on the expansion of credit to support consumer demand and property and financial speculation. As Aglietta argued 'the financial crisis has invalidated this particular logic of capitalism. In the absence of a destruction of capital values and deleveraging, it has, however, not led to a renewal of productive investment.

For Keynes, Kalecki and Minsky investment is a part of aggregate demand and investment drives profits rather than vice versa: investment increases output and producer and consumer income, while increased income enables the increase in output to be sold at prices that provide a markup on costs affording a return on the capital advanced [27;31; 40]. According to Keynes [31] what mattered was that marginal efficiency of capital exceed the rate of interest: if the expected profitability associated with the purchase of additional capital exceeds the rate of interest, investment will go ahead. Keynes $[30 ; 31]$ also argued that capital would eventually cease to be scarce and that interest rates would fall close to zero, leading to a situation in which investment and growth would depend solely on the marginal efficiency of capital. According to Minsky [40] the expected profits of indebted investors must also suffice to validate/ recover the payment commitments arising from earlier investments.

For Kalecki [27, p. 78-79] in the case of the simplest of models it is capitalist's aggregate 'investment and consumption decisions which determine profits, and not viceversa.' Causality runs from investment and capitalist consumption to profit. The more capitalists spend as a class, the more profit they will make. According to Minsky [40, p. 184] causality 'runs from investment and government spending to taxes and profits. On this view in recessions investment depends on profitability, but, as profits depend themselves on previous investment, it is investment that ultimately drives economic development.

\footnotetext{
${ }_{4}^{4}$ In the productive sector profits derive from advancing one's own and borrowed capital to provide goods and services. As the difficulty of making profits from productive activities increased, the attractiveness of making money via finance rose, especially in countries with major financial sectors. In the banking sector profitability derives from the volume of financial transactions and from the ability to create new revenue-earning financial assets through the creation of credit: as long as loans yield higher rates of interest than deposit liabilities or borrowing, expanding assets increases net income, provided that at the end of the day sufficient new income is created to enable repayment of loans. This problem of debt repayment plagues the global system today.

${ }_{5}$ In these circumstances changes in corporate profits depend on changes in the value of fictitious capital (which depends on stock and bond market prices and interest rates). These valuations were often radically different from those deriving from the real earning on advanced capital.
} 


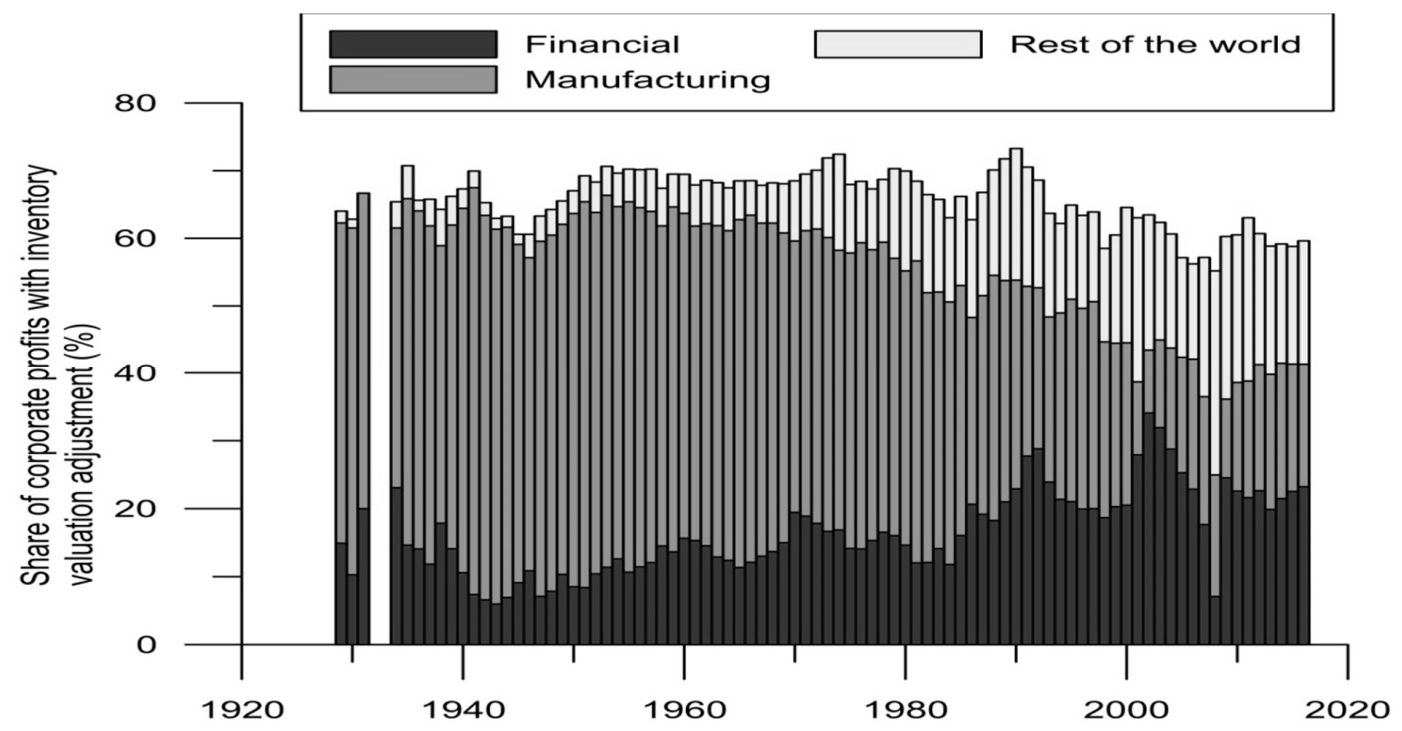

Fig. 4. Structure of US corporate profits, 1929-2016

In this light some Keynesian economists have identifies a problem of secular stagnation $[20 ; 34 ; 49]$. The core claim is that recent interest rates are too high, and that capitalist economies can grow more rapidly only if investment and consumption increase as a result of further reductions in real interest rates through inflation and speculation. At present however nominal interest rates are near zero and subject to a permanent zero lower bound, making secular stagnation unavoidable. A multiplicity of other explanations of insufficient effective demand have been put forward including a decline in the share of wages in national income, greater inequality, and monopolistic mark ups on costs. Many of these arguments are less pessimistic than the secular stagnation thesis in the sense that they identify reforms that might raise investment.

And yet a clear implication of all of these arguments is also however that the marginal efficiency of productive investment is low and that there is therefore a dearth of profitable productive investment opportunities. In the US case moreover it is far from clear that investment drives profitability rather than vice-versa. In the US profits peaked several quarters before the recessions in 1974-75, 1980-82, 1990-92, 2001, and 2008-09, while investment peaked later, almost immediately before the recession. After the start of the recession, profits recovered before investment. This evidence suggests that it is low rates of return on productive investment that are driving stagnation $[50]^{6}$.

From the 1970s there was also a massive offshoring of jobs from developed to emerging countries. As will be seen, the capacity of some emerging economies to take advantage of this global shift played an important role in relocating the world's cen-

\footnotetext{
${ }^{6}$ Marx argued that the value of the means of production relative to the value of wages (for the system as a whole) has a propensity to increase over time tending to reduce the rate of profit. This decline can be offset by increases in the rate of surplus value or a reduction in capital costs possibly through a destruction of capital as occurred in the Second World War.
} 
tre of economic gravity. At the same time relocation helped counter the decline in profitability of US corporations. First, US corporations replaced expensive domestic with cheaper foreign labor. Second, trade with emerging countries provided low cost finished and semi-finished goods, reducing domestic investment and affording large profits through their sale in rich country markets. Although domestic operations realized these profits, the source was cheap imports. Cheap imports also reduced the cost of living in the US and other industrialized countries, contributing to the decline in the cyclical volatility of GDP referred to as the Great Moderation (Figure 2). Third, the accumulation of foreign reserves and purchase of US securities by US trade partners to insure themselves against financial crises reduced nominal and inflation-adjusted interest rates and reduced yields. The consequence was an increase in the price of securities, increased financial sector activity and profits and a sharp increase in credit fueled demand. Simply speaking, after the financial crisis corporate profitability was supported by the decision of the US government and the Federal Reserve to rescue the private sector, and subsequently to purchase billions of dollars of US Treasury securities and private mortgage backed securities.

As the Stolper-Samuelson theorem shows however under competitive conditions, as long as imported good(s) continue to be produced domestically, at least one factor of production is rendered worse-off by trade liberalization [48]. In the US and Europe the losers from the offshoring of jobs were members of the manual working class. Increased trade led to job displacement and income losses as a result of competition with workers living in countries with different social norms and regulatory systems (reflecting the unevenness of development). At the same time immigration intensified domestic job market competition, eventually contributing to deep social and political cleavages in economically advanced countries.

In a sense therefore globalization offset the stagnation of advanced country growth at the expense of significantly reduced social cohesion, while contributing to the emergence of new rising powers. More important in many respects were however the ways in which a small number of countries were able to mitigate the difficulties they faced through their capacity to appropriate wealth created in the rest of the world. These countries usually had extensive past and present trade and investment activities and came to dominate global finance and commerce. Until the recent emergence of China, the main centers were the US and the UK with smaller centers in Japan, France and Germany, regional centers in Hong Kong and Singapore and fund management centers in Switzerland and Luxembourg and a host of offshore tax havens. As concentrations of the activities of unevenly developed financial markets, these centers not only generate significant revenues and capital gains but are also sources of power and control for the corporations, individuals and governments with privileged access to them.

The evolution of the shares of outstanding cross-border claims and liabilities of banks located in different countries. Claims are bank loans to other countries, while liabilities are deposits from other countries. Together these claims and liabilities are correlated with the economic power and influence and transactional revenues of these 
countries from trading in foreign exchange, securities and derivatives. At the end of 1977 the US accounted for $12.6 \%$, while the UK, which had developed as a centre for the Euromarkets and an intermediary meeting the financial needs of a growing internationalization of capital, accounted for $26.1 \%$. At the start of 2017 the corresponding figures were $11.7 \%$ and $17.0 \%$. Figure $5 \mathrm{~B}$ records the same data by country of ownership of the banks rather than their geographical location. At the end of 1983 the US accounted for $25.3 \%$. At the start of 2017 this figure had dropped to $12.4 \%$.

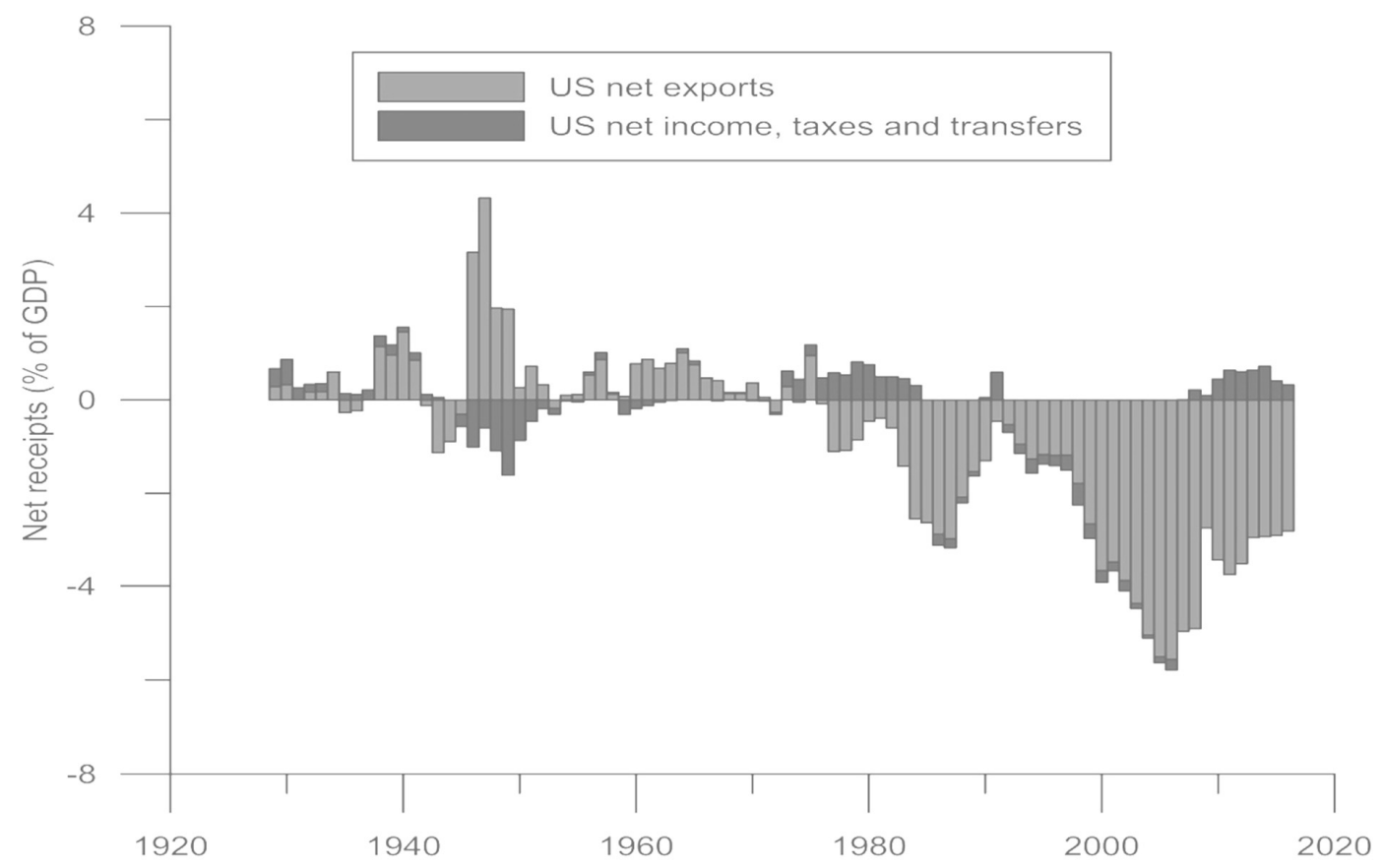

Fig. 5. US balance of payments, 1929-2016

The US role in the international system derived from its role in setting the ground rules for the world monetary system established after the Bretton Woods agreements. The initially anticipated dollar shortage turned however into a glut. As the US used the dollar to pay for imports which started to exceed exports (Figure 5) and to finance net outward investment, overseas dollar holdings came to exceed US gold reserves at the official price of $\$ 35$ troy ounce. To deal with this problem, which derived in part from the cost of the Vietnam War and US social programmes and in part from a decline in US competitiveness, in 1971 the US severed the link with gold and ended the Bretton Woods fixed exchange rate regime.

At that stage however the US dollar remained central, as it accounted for $84.5 \%$ of foreign currency reserves, as most trade was denominated in dollars and as the US had the largest capital markets [41]. To preserve its dominance, in 1974, the US persuaded Saudi Arabia and subsequently other Middle Eastern OPEC states to denominate the price of oil in dollars and to use part of the trade surpluses generated by the 1973-74 and 1979-80 oil price hikes to purchase US Treasury securities. OPEC dollar surpluses 
were also deposited in banks in the US and UK in particular, and were in some cases recycled as loans to developing countries, laying the ground for the debt crises of the 1980s. These crises in turn weakened the political position of the Global South and the saw the morphing of the International Monetary Fund (IMF) into an instrument for crisis management and opening up enfeebled emerging economies. Other countries were forced to compete for and hold dollar stocks to service dollar-denominated payments and accumulate dollar reserves to sustain the exchange value of their own currencies and protect themselves against speculative attacks. As these stocks were not converted into other currencies, and as OPEC and other surplus countries purchased US securities, pressures on the US exchange rate were removed, enabling the US to embark on a national and global strategy of capital account liberalization and opening a new era of global financial markets (Figure 1).

The domination of global currency deals by the dollar generates a series of advantages for the US. First the US gains from international seigniorage: insofar as the fiat dollars used to purchase imports are not used to purchase US goods and services but instead go into circulation in other countries, the Federal Reserve can simply print dollars, appropriating wealth from the rest of the world, provided it does not destabilise the international monetary system.

Second the US has managed to finance large external trade deficits (and federal government deficits) by borrowing in its own currency at an extremely low cost. In the past surplus countries such as Saudi Arabia, Japan and China have purchased US Treasury securities and other dollar denominated assets. In 2014 to 2017 nearly twothirds of official foreign exchange reserves were held as dollars. These holdings reduce US yields, compensate for the low savings rate in the US and underpin consumer and government borrowing. US saving declined as a share of GDP from peaks of $16 \%$ in 1942, 12.7 in 1965, 11.0 in 1973, 9.5 in 1978, 6.2 in 1999 to 3.3 in 2015.

Third the dollar share of the credit market is the largest in the world. Privileged access to this market, the avoidance of exchange rate risk and relatively low rates of interest are important US economic advantages. In particular the interest costs of US foreign borrowing are far smaller than the rates of return on US foreign investment, enabling the US to secure a positive net income position despite the fact that foreigners own more assets in the US than the US does in other countries?

Fourth, as most trade and finance is denominated in US dollars, just about every country is subject to US commercial rules. Moreover the US can seriously damage other countries by cutting them off from the US banking system through which dollar transactions must normally pass and by exposing non-US banks to sanctions if they deal with a country the US wants to isolate.

As finally one of the centers for the world's major equity markets with access of world funds and with high equity valuations, the US and its corporations have finally

\footnotetext{
7 In 2016 US income from investments and trade in foreign equities and bonds amounted to $\$ 844.3$ billion. US payments to the rest of the world on its liabilities arising from foreign investments in the US stood at $\$ 647.2$ leaving a net income of \$197.1 billion (Figure 5).
} 
considerable resources to deploy to assume control of global economic assets and the dividend streams they generate.

The stagnation of the US and other western powers is one aspect of U\&CD. As this section has shown however the US and a number of other western countries continued to occupy a dominant position in the global system tempering economic decline through the continued appropriation of resources from the rest of the world ${ }^{8}$. These advantages were closely related to role of the dollar, control over oil and gas from petro-states and the willingness of countries with large trade surpluses to purchase US securities. These transfers could however not arrest structural decline. More importantly, this position of dominance was eroded as latecomers embarked on catch-up development, as their role in the international order increased and as US attempts to use its military capacity to maintain its position of dominance failed, creating instability and difficult to resolve security issues.

\section{The rise of China}

Until the eighteenth century China was not just a great civilization but also a world leader in science and technology. After 1840 internal drivers of decline were reinforced by the commercial penetration of foreign colonial powers and Japan's attempt at conquest. In 1949 the new China was the poorest country in the world. From that point in time however China embarked on catch-up industrialization and urbanization drawing on latecomer advantage to develop industries using some of the latest technologies, jumping steps and rapidly increasing labor productivity [36]. As already mentioned, the main source of productivity growth was not however innovation but capital accumulation and the replication of existing technologies. In this case output increases in proportion to inputs of capital, labour and land. The innovation of new technologies, products and organizational models does of course raise output per unit of input. The main driver was nevertheless the accumulation of capital and the mobilization of labour. Indeed, even in the US since 1947 'the great preponderance of economic growth ... involved the replication of existing technologies through investment in equipment, structures, and software and expansion of the labor force' $[26, \mathrm{p} .1]$.

As a result in 1960 to 2016 China's share of world GDP at current exchange rates rose from $4.3 \%$ to $14.7 \%$, making it the second largest economy in the world after the US (22.9\%). In 2016 China was the world's largest exporter, supplying $13.1 \%$ of all exports, accounted for $12.6 \%$ of the stock of inward foreign direct investment and $4.5 \%$ of the stock of outward investment ${ }^{9}$. At the end of June 2017 Chinese foreign exchange reserves stood at US\$ 3.087 trillion stood having reached US\$ 3.993 in June $2014^{10}$.

\footnotetext{
8 In the aftermath of the financial crisis quantitative easing drove down interest rates and led to significant increases in dollar debt outside the US including in many emerging economies increasing vulnerability to rising dollar yields and dollar appreciation and creating a potential stream of revenue for the US.

9 United Nations Conference on Trade and Development (UNCTAD). 2017. Statistics. URL: http://unctad.org/en/Pages/ Statistics.aspx (accessed: 01.10.2017).

${ }^{10}$ State Administration of Foreign Exchange (China). Forex reserves. URL: http://www.safe.gov.cn/wps/portal/english/ Data (accessed: 01.10.2017).
} 
The Chinese government has used these reserves to recapitalize its state-owned banks and finance overseas investment by State-Owned Enterprises and private companies in Africa, South America and the Pacific. According to IMF forecasts Chinese savings will reach $\$ 7,374.1$ billion in 2022 compared with $\$ 4,615.2$ billion in North America and $\$ 4,345.9$ billion in the EU. The assets of China's development banks outstrip those of the World Bank (Figure 6).

This remarkable transformation involved the joint transformation of economic structures and public institutions, designed to move the country forward economically, while dealing with the contradictions generated by earlier phases of development [12]. Up to 1978 these socio-economic transformations were driven by the establishment of a unified socialist state. In 1978 the Third Plenary Session of the Eleventh Central Committee of the Communist Party of China (CPC) confirmed the decision to embark on reform and opening up with a view to the preservation of the integrity of the country and the leading role of the CPC and the establishment of a socialist market economy with Chinese characteristics.

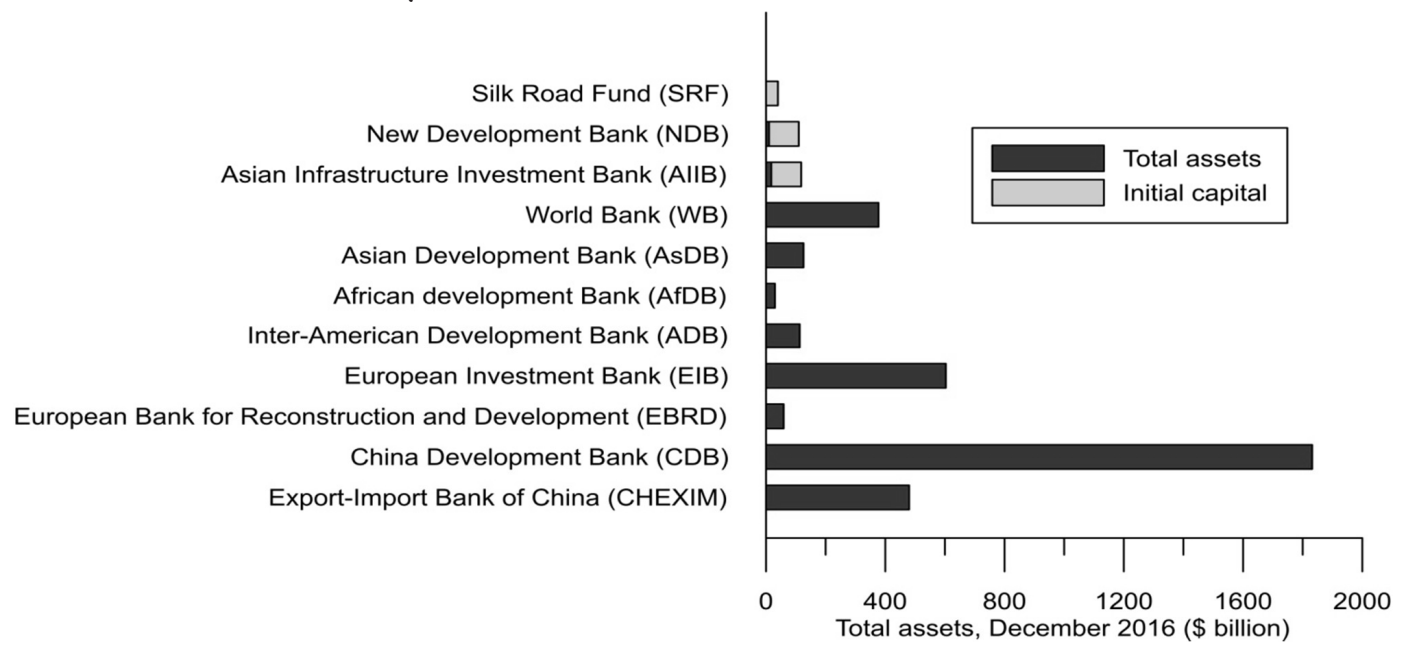

Fig. 6. Development finance: total assets and initial capital of international and Chinese development banks, 2016

Agricultural reform, the establishment of Township and Village Enterprises, the rationalization and/or sale of loss-making SOEs and the attraction of foreign investment into special zones to serve markets separate from those served by potentially vulnerable domestic producers saw a massive transfer of labour from agriculture to industry and services and from the countryside to the city. In 1978 82\% of the population was rural and $71 \%$ were farmers accounting for just $28 \%$ of national output. By 2015 these figures stood at 47\%,34\% and 10\%. At the time of the 2010 Census 260 million mainly young rural people worked as floating workers in China's cities [13].

These transformations derived from exceptionally high rates of saving, investment and capital accumulation in urban and rural infrastructure, plant and equipment. In China since 1978 the share of investment in GDP increased. The lowest share was 
32\% in 1982 and 1983 and the highest was 48\% in 2011. An exceptional high volume of investment in urban and rural infrastructure, plant and equipment was a characteristic of East Asian development and was a major driver of China's growth. China is characterized by state ownership of most of the banking system and the development of a very strong SOE sector. The existence of significant state assets generates revenue streams that provide the government with resources to fund economic and social infrastructure and services and reduce reliance on taxation and interest-incurring public debt, provided these assets are used efficiently [39]. In China public investment was and is a major driver of growth and productivity.

In the next 15 years the size of the urban population will increase by some 300 million people driving domestic growth through massive investments in new infrastructure, housing and commercial and industrial property, significant increases in urban employment and urban services, increased social protection and reduced cautionary savings [37].

Although the current degree of inequality is unacceptable and poverty remains a serious problem especially in remote mountain areas, China's growth has raised all boats but at different speeds. Almost all urban Chinese and the top two rural deciles were among the groups with the greatest increases in real income in the world in 1988 to 2008, although relative and especially absolute increases were greater for higher income groups (Figure 7). In China the average real income in poor rural counties also increased. Conversely people at the lower end of the income distribution in rich countries lost ground contributing to the decline in social cohesion noted earlier.

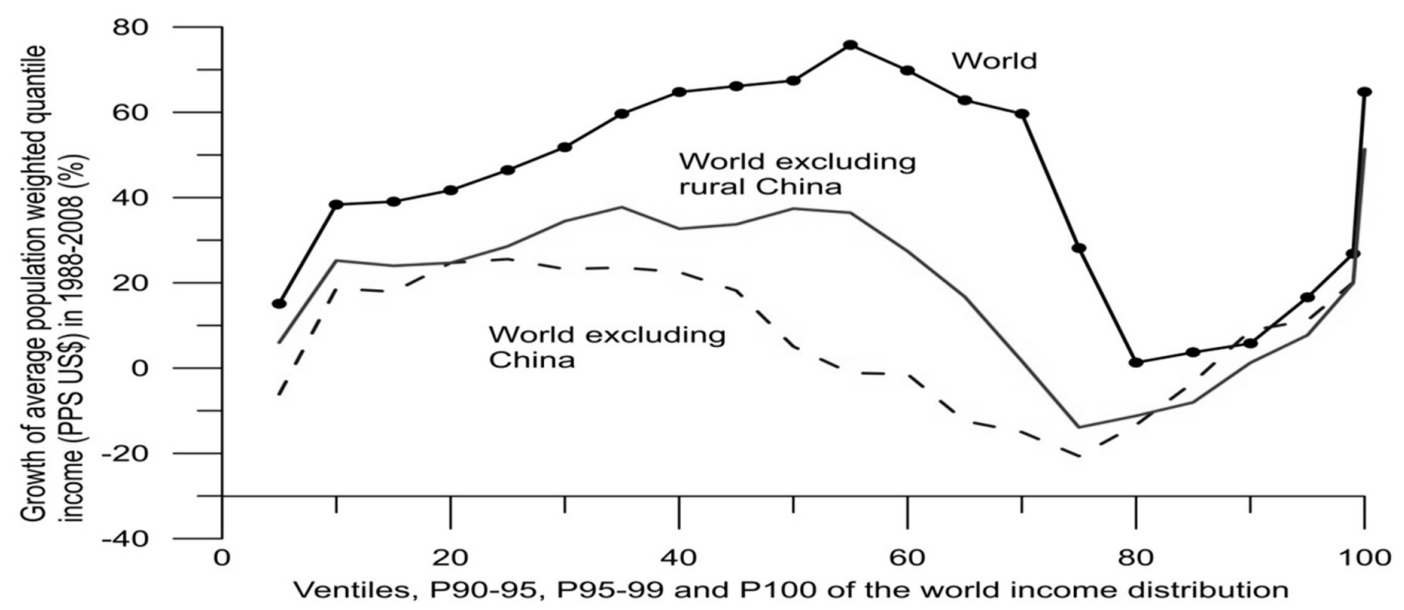

Fig. 7. Global growth incidence curves: relative increase in real income by percentile of the world income distribution, 1988-2008 [35; 47].

China managed to get close to the technology frontier often in clusters of industries in geographically fragmented value chains [8]. Catch-up depends critically, however, on governance, policy and economic and cultural capacities of adaptation and assimilation. Countries/regions that have established early domestic indus- 
trial nodes find growing from their initial positions extremely difficult. As concepts of U\&CD suggest, transnational corporations are very resistant to domestic content and technology transfer requirements and use their influence with international organizations and their domestic governments to unravel policy restrictions. A strong state, an attractive investment environment and an increasingly coveted domestic market provided China with the means to negotiate more equitable terms and conditions.

China's success owes no small amount to these circumstances and the capacity of the Chinese government to adopt an effective export-oriented growth model. The government delivered collective services, infrastructure and stability. China established control over its capital account enabling the Central Bank to accumulate reserves and the government to create a Sovereign Wealth Fund. The accumulation of reserves put downward pressure on China's exchange rate, reinforcing export competitiveness and enabled China to provide credit to developed countries importing its exports. China mobilized domestic savings alongside foreign direct investment (FDI) to finance investment. As China's development of an industrial policy combining effective protection with export promotion and some technology transfer showed, an ability to take advantage of globalization depends on state capacity, which was actually reduced in countries that adopted neo-liberal reform agendas in line with the open door interests of foreign capital. As concepts of U\&CD imply, the exploitation of latecomer advantage depends critically on the grounding of economic models in supportive and capable institutional configurations.

The rise of China poses major challenges to US domination of world economy, of finance and of the World Bank and the IMF. A new balance of economic forces can change world trends. In 2009-16 China accounted for 69.7 to $92.9 \%$ of the US current account deficit. China provides an alternative source of funds for countries not favored by the World Bank and the IMF. In 2014 Brazil, Russia, China and India, South Africa established the New Development Bank. Mainly funded by China and headquartered in Shanghai, it will finance trade and investment contracts outside the Anglo-American system that do not use dollars. The same year saw the establishment of the Asian Infrastructure Investment Bank which the US failed to prevent its allies from joining. China's authorities have secured the inclusion of the Renminbi in the IMF's Special Drawing Rights, making the renminbi global and a world reserve currency. At the same time international transactions priced in the Renminbi have increased. Although China is far from able to offer the global system an alternative to the dollar, it along with other emerging powers have challenged and started to erode the privileged and dominant position of the US.

In the last one hundred years there were a series of important turning points in global development of which the present is merely the latest. Amongst these recent changes is the end of the US and NATO dominated unipolar world system established 
after the collapse of the Soviet Union and Communism in Eastern Europe. This change is a result of the relative decline of developed countries on the one hand and the rise of emerging powers on the other. These two trends are a result of internal drivers of change and of international interactions which both work to amplify and reduce disparities in economic development and power, and are associated with movements in the direction of a multi-polar multi-civilizational world system.

These recent trends in global development derive in part from a crisis of profitability and a wave of globalization that dates from the middle of the 1970s and the inability of neo-liberal economic strategies to restore western growth, although the development of global finance enabled some developed countries to mitigate the economic effects through the appropriation of income from the rest of the world. These gains however predominantly favored the rich and powerful. This neo-liberal strategy was closely associated with the drive in a unipolar world to extend western values, western political systems and open door measures to all parts of the globe with colour revolutions and in some cases war. These steps undermined the principles of sovereignty and balance of power that had underpinned the post-World War Two international order on the one hand and failed to deliver promises of generalized prosperity on the other generating increased global instability.

The rise in income in some developing countries reflects the way in which first Japan, the four Asian Tigers, and other developing countries including in particular China, India and a number of other Asian economies successively managed to exploit the advantage of backwardness, finally spurring demand for mineral exports from Africa and elsewhere.

The countries that grew were all countries that did not pursue the neo-liberal agenda of the World Bank and the IMF. Washington Consensus countries in Latin America, Africa and some transition economies were increasingly subjected to capitalist market logic. Transnational capital was granted increasing global economic and political power, and decision making was increasingly permeated by multinational companies, transnational media organizations, investment banks, hedge funds, credit rating agencies, accountancy firms, management consultancies and international organizations controlled by western powers and promoting western values.

Economic and financial globalization which, as already mentioned, was a response to a largely unresolved crisis of domestic profitability in the 1970s and did not arrest a secular slowdown in western economic growth, ended with an economic crisis that opened with the western financial crisis and was followed by subsequent crises of government debt and a Euro-zone crisis from which the countries involved have not yet recovered. Added to them recently were political crises reflecting deep social and political divisions in developed countries, a lack of secure and evenly distributed living standards and the deficiencies of the western political order and political establishment.

The stagnation of high income countries has depressed international trade and investment. The weakness of demand contributed to slower growth of many emerging 
economies. Chinese growth on which world growth increasingly depended has also slowed in a world in which low growth and high levels of inequality dominate political agendas.

A response in some quarters is a move in the direction of de-globalization. Globalization involved not just increased economic interdependence but also increased ecological, political and social interdependence. Today many people and many things from diseases to dollars to news and greenhouse gases can reach almost anywhere in the world. As a result what happens in one place affects others, what one person does affects others requiring an operating system in which obligations to others are examined and negotiated. These interdependencies are not easily unraveled if at all. And yet moves are foot to reduce some of the vulnerabilities to which increased neo-liberal globalization led.

At a time however when the neo-liberal globalist agenda is under attack, other countries such as China along with other emerging powers are attempting to map out a new model of inclusive globalization that is capable of serving the needs of everyone, that benefits all countries and people, addresses inequality and poverty and manages global risks. China has suggested a morality/justice-interest (Yi and $\mathrm{Li}$ - 义 and 利) concept of international relations, and has established a number of new financial instruments (Figure 7). India's 2014 Project Mausam aims to re-establish maritime communications between countries of the Indian Ocean world, while a North-South International Transport Corridor from India via Iran, Azerbaijan, Russia and Europe is under development. Aimed at Eurasian integration China's Belt and Road Initiative is driving infrastructure (roads, railways, ports, airports, telecommunications networks, pipelines, development zones and cities) and economic development diversifying trade routes and reducing Chinese dependence on the Straits of Malacca. The US\$ 46 billion China-Pakistan Economic Corridor (CPEC) connects relatively underdeveloped southern Xin Jiang and neighbouring landlocked countries in Central Asia along the Karakoram Highway through northern Gilgit-Baltistan to the megaport of Gwadar in the Arabian Sea on the Indian Ocean rimland. Other corridors will connect western China with Myanmar, Bangladesh, Sri Lanka, the Maldives and West Africa, while others will connect it westwards across Central Asia and Russia to the west of Eurasia and Africa. Should current trends in relative growth continue, and should these projects succeed, in 2050 the economic centre of gravity of the world will have moved from the mid-Atlantic in 1980 to somewhere between India and China [44] and along with it the map of economic development and interactivity.

\section{References}

1. Abramovitz M. Catching up, forging ahead, and falling behind. Journal of Economic History, 1986, 46(2), pp. 385-406.

2. Aglietta M. Régulation et crises du capitalisme. L'expérience des États-Unis [Regulation and cri- ses of capitalism. The United States experience]. Paris: Calmann-Lévy, 1976. 334 p.

3. Aglietta M. America's slowdown. New Left Review, 2016, no. 100, pp. 119-129.

4. Historical Sociology and World History. Uneven 
and Combined Development over the Longue Durée. Ed. by Anievas A., Matin K. London, Rowman \& Littlefield International Publ., 2016.318 p.

5. Arrighi G. Adam Smith in Beijing: Lineages of the Twenty-first Century. London and New York, Verso Publ., 2007. 418 p.

6. Braudel F. Ciyilisation matérielle, Economie, et Capitalisme, XVème-XVIIIème Siècle. [Vol. I: Les Structures du Quotidien. Vol. 11: Les Jeux de l'Echange. Vol. 111: Le Temps du Monde]. Paris, Armand Colin, 1979. 736 p.

7. Brenner R. The Economics of Global Turbulence: The Advanced Capitalist Economies from Long Boom to Long Downturn, 1945-2005. London, Verso Publ., 2006. 369 p.

8. Breznitz D., Murphree M. Run of the Red Queen: Government, Innovation, Globalization, and Economic Growth in China. New Haven and London, Yale University Press Publ., 2011. 298 p.

9. Callinicos A., Rosenberg J. Uneven and combined development: the social-relational substratum of 'the international'? An exchange of letters. Cambridge Review of International Affairs, 2008, no. 21(1), pp. 77-112.

10. Davidson N. How Revolutionary Were the Bourgeois Revolutions? Chicago, United States, Haymarket Books Publ., 2012. 840 p.

11. Dunford M. Theories of regulation. Environment and Planning D-Society \& Space, 1990, 8(3), pp. 297-321.

12. Dunford M. Chinese economic development and its social and institutional foundations. Dunford M., Liu W.D. The Geographical Transformation of China Preface and acknowledgements. Vol. 133. Abingdon, Routledge Publ., 2014. 372 p.

13. Dunford M., Liu W.D. Uneven and combined development. Regional Studies, 2017, 51(1). pp. 69-85.

14. Esping-Andersen G. The Three Worlds of Welfare Capitalism. Cambridge, Polity Press Publ., 1993. $260 \mathrm{p}$.

15. Frank A.G. ReOrient. Global economy in the Asian age. Berkeley, University of California Press Publ., 1998. 416 p.

16. Gordon R. J. The Rise and Fall of American Growth: The U.S. Standard of Living since the Civil War (The Princeton Economic History of the Western World). Princeton, New Jersey, Princeton University Press Publ., 2016. 784 p.

17. Grinin L., Korotayev A. Great Divergence and Great Convergence: a Global Perspective. Switzerland, Springer Publ., 2015. 251 p.

18. Grinin L., Korotayev A., Tausch A. Economic Cycles, Crises, and the Global Periphery. Switzerland, Springer Publ., 2016. 265 p.
19. Hall P.A., Soskice D.W. Varieties of Capitalism. The Institutional Foundations of Comparative Advantage. Oxford, Oxford University Press Publ., 2001. 560 p.

20. Hansen A.H. Full recovery or stagnation. New York, Norton Publ., 1938. 350 p.

21. Harootunian H. Marx After Marx: History and Time in the Expansion of Capitalism. New York, Columbia University Press Publ., 2015. 312 p.

22. Harvey D. The new imperialism. Oxford, Oxford University Press Publ., 2003. 288 p.

23. Hobsbawm E. The age of extremes. A history of the world, 1914-1991. London, Michael Jospeh Publ., 1994. 627 p.

24. Hobson J.A. Imperialism, A study. New York, James Pott\&Company Publ., 1902. 412 p.

25. Huntingdon S.P. The Third Wave: Democratization in the Late Twentieth Century. Norman, Oklahoma, University of Oklahoma Press Publ., 1993. 284 p.

26. Jorgenson D.W., Ho M.S., Samuels J.D. Longterm stimates of U.S. productivity and growth. Paper presented at the Third World KLEMS Conference. Growth and Stagnation in the World Economy. Tokyo, 2014. Available at: http://www.worldklems.net/conferences/worldklems2014/worldklems2014_Ho.pdf (accessed: 01.10.2017).

27. Kalecki M. Selected essays on the dynamics of the capitalist economy, 1933-70. Cambridge, Cambridge University Press Publ., 1971. 206 p.

28. Kennedy P. The Rise and Fall of the Great Powers: Economic Change and Military Conflict from 1500 to 2000. New York, Vintage Books Publ., 1987. 704 p.

29. Keynes J.M. The economic consequences of Mr. Churchill (1925). Essays in persuasion. London, Macmillan \& Company Publ., 1931. Pp. $207-$ 230.

30. Keynes J.M. Economic Possibilities for our Grandchildren (1930). Essays in persuasion. London, Macmillan \& Company Publ., 1931. Pp. 321-332.

31. Keynes J. M. The General Theory of Employment, Interest and Money. London, Macmillan Publ., 1936. $168 \mathrm{p}$.

32. Kliman A. The failure of capitalist production. Underlying causes of the great recession. London, Pluto Press Publ., 2012. 256 p.

33. Kondratieff N.D. Die langen Wellen der Konjunktur [The long waves of the ecomomy). Archiv für Sozialwissenschaft und Sozialpolitik, 1926, no. 56(3), pp. 573-609.

34. Krugman P. Four observations on secular stagnation. Secular stagnation: facts, causes and 
cures. Ed. by C. Teulings \& R. Baldwin. London, CEPR Press Publ., 2014. Pp. 61-68.

35. Lakner C., Milanovic B. Global Income Distribution: From the Fall of the Berlin Wall to the Great Recession. World Bank Economic Review, 2016, no. 30(2), pp. 203-232.

36. Lin J.Y. The rise of China and its implications for economics and other developing countries. Area Development and Policy, 2017, no. 2(2). pp. 110119.

37. Liu W., Dunford M., Song Z., Chen M. Urbanrural integration drives regional economic growth in Chongqing, Western China. Area Development and Policy, 2016, no. 1(1), pp. 132154.

38. Matin K. International relations in the making of political Islam: Interrogating khomeini's 'islamic government'. Journal of International Relations and Development, 2013, no. 16(4), pp. 455-482.

39. Meade J.E. Efficiency, equality, and the ownership of property. London, Allen \& Unwin Publ., 1964. $92 \mathrm{p}$.

40. Minsky H.P. Stabilizing an unstable economy (1986). New York, McGraw-Hill Publ., 2008. 350 p.

41. Norfield T. The city. London and the global power of finance. London, Verso Publ., 2016. 288 p.

42. Obstfeld M.,Taylor A.M. Globalization andf capital markets. Globalization in Historical Perspective. Ed. by M.D. Bordo, A.M. a. Taylor, \& J.G. Williamson. Chicago, University of Chicago Press Publ., 2003. Pp. 121-187.

43. Polanyi K. The Great Transformation: the Political and Economic Origins of Our Time. Boston, MA., Beacon Press Publ., 1944. 360 p.

44. Quah D. The Global Economy's Shifting Centre of Gravity. Global Policy, 2011, no. 2(1), pp. 3-9.

45. Rosenberg J. Kenneth Waltz and Leon Trotsky: Anarchy in the mirror of uneven and combined development. International Politics, 2013, no. 50(2), pp. 183-230.

46. Rosenberg J. Uneven and combined Development: 'The International' in theory and history.
Historical Sociology and World History. Uneven and Combined Development over the Longue Durée. Ed. by A. Anievas \& K. Matin. London, Rowman \& Littlefield International Publ., 2016. Pp. 17-30.

47. Rosnick D. The Incredible Story of Developing Country Income Growth: Was it Just China? Available at: http://cepr.net/blogs/cepr-blog/ the-incredible-story-of-developing-countryincome-growth-was-it-just-china (Accessed: 01.10.2017).

48. Stolper W.F., Samuelson P.A. Protection and real wages. The Review of Economic Studies, 1941, no. 9(1), pp. 58-73.

49. Summers L.H. Reflections on the "new secular stagnation hypothesis. Secular stagnation: facts, causes and cures. Ed. by C. Teulings \& R. Baldwin. London, CEPR Press Publ., 2014. Pp. $27-$ 38.

50. Tapia Granados J.A. Does Investment Call the Tune? Empirical Evidence and Endogenous Theories of the Business Cycle. Contradictions: Finance, Greed, and Labor Unequally Paid. Ed. by P. Zarembka. Bingley, UK, Emerald Group Publishing Limited Publ., 2013. Pp. 229-259.

51. Trotsky L. The Third International after Lenin. Available at: https://www.marxists.org/archive/trotsky/1928/3rd/index.htm (accessed: 01.10.2017).

52. Trotsky L. The history of the Russian Revolution. Available at: https://www.marxists.org/archive/ trotsky/1930/hrr/ (accessed: 01.10.2017).

53. Van der Linden M. The 'law' of uneven and combined development: Some underdeveloped thoughts. Historical Materialism-Research in Critical Marxist Theory, 2007, no. 15(1), pp. 145165.

54. Zhu Y.-H. Gao si zai yun. zhongguo xingqi quanqiu zhixu chongxu [Broad and far-sighted perspectives from the sky. The rise of China and reorganization of the global order]. Beijing, Beijing renmin daxue chubanshe [Beijing Renmin University Press], 2015. (in Chinese).

\section{About the authors:}

Michael Dunford-Emeritus Professor, School of Global Studies, University of Sussex; CAS Senior International Scientist, Institute of Geographical Sciences and Natural Resources Research, Chinese Academy of Sciences, 11A, Datun Road, Chaoyang District, Beijing, 100101, China. E-mail: M.F.Dunford@sussex.ac.uk.

Liu Weidong - Professor in Economic Geography, Deputy Head of the Department of Human Geography and Regional Development Institute of Geographical Sciences and Natural Resources Research, Chinese Academy of Sciences, 11A, Datun Road, Chaoyang District, Beijing, 100101, China.

E-mail: liuwd@igsnrr.ac.cn. 


\title{
СТОЛЕТИЕ СМЕШАННОГО НЕРАВНОМЕРНОГО РАЗВИТИЯ: ЭРОЗИЯ ГЕГЕМОНИИ США И ВОЗВЫШЕНИЕ КИТАЯ
}

\author{
Майкл Данфорд, Лю Вэйдун \\ DOI 10.24833/2071-8160-2017-5-56-7-32
}

Институт географических исследований и изучения природных ресурсов Китайской академии наук

Концепция смешанного неравномерного развития, в рамках которой взаимосвязи и взаимодействия разных обществ формируются и сочетаются со своими внутренними структурами, используется для изучения движущих сил текущей стадии глобального развития за 100 лет с 1917 г. Это понятие было придумано левым теоретиком и одним из лидеров ВКП(б) Львом Троцким с целью объяснения особенности развития имперской России. В настоящее время оно применяется для рассмотрения различных случаев политического и экономического развития на глобальном уровне. Концепция смешанного неравномерного развития позволяет учитывать как внутригосударственные, так и внегосударственные факторы, включая эволюцию политических режимов, динамику международной торговли.

В статье большое внимание уделяется движущим факторам мирного экономического спада в США и западном мире - как этот спад был смягчён волной производственной и финансовой глобализации, которая сама по себе способствовала росту ряда развивающихся экономик с экономическим, политическим и культурным потенциалом, а также подтолкнула их использовать полученные преимущества для продвижения полицентричного и многоцивилизационного мира и, возможно, более инклюзивной модели развития. Одной из таких стран является Китай, власти которого нашли способ совместить протекционизм в отношении внутреннего рынка сактивным продвижением экспорта, заимствованием технологий и сохранением текущей модели управления. Авторы приходят к выводу, что ключевым фактором успеха КНР на этом направлении была постепенность политического развития, сохранение государственной состоятельности (state capacity) и сдержанное отношение к господствовавшим неолиберальным подходам к формулированию экономического курса.

Таким образом, в статье рассматривается политическая экономия глобальных сдвигов власти и их долгосрочные перспективы. Существующие тенденции глобальных рынков, по мнению авторов, благоприятны для КНР.

Ключевые слова: неравномерное и комбинированное развитие, Соединённые Штаты, Китай, реальная и финансовая глобализация.

\section{Список литературы}

1. Abramovitz M. Catching up, forging ahead, and falling behind // Journal of Economic History. 1986. No. 46(2). Pp. 385-406.

2. Aglietta M. Régulation et crises du capitalisme. L'expérience des États-Unis
[Regulation and crises of capitalism. The United States experience]. Paris: Calmann-Lévy, 1976. 334 p.

3. Aglietta M. America's slowdown // New Left Review. 2016. No. 100. Pp. 119-129.

4. Anievas A., Matin K. (Eds.). Historical 
Sociology and World History. Uneven and Combined Development over the Longue Durée. London: Rowman \& Littlefield International, 2016. 318 p.

5. Arrighi G. Adam Smith in Beijing: Lineages of the Twenty-first Century. London and New York: Verso, 2007. 418 p.

6. Braudel F. Ciyilisation matérielle, Economie, et Capitalisme, XVème-XVIIIème Siècle. [Vol. I: Les Structures du Quotidien. Vol. 11: Les Jeux de l'Echange. Vol. 111: Le Temps du Monde]. Paris: Armand Colin, 1979. 736 p.

7. Brenner R. The Economics of Global Turbulence: The Advanced Capitalist Economies from Long Boom to Long Downturn, 1945-2005. London: Verso, 2006. 369 p.

8. Breznitz D., Murphree M. Run of the Red Queen: Government, Innovation, Globalization, and Economic Growth in China. New Haven and London: Yale University Press, 2011. 298 p.

9. Callinicos A., Rosenberg J. Uneven and combined development: the social-relational substratum of 'the international'? An exchange of letters // Cambridge Review of International Affairs. 2008. No. 21(1). Pp. 77-112.

10. Davidson N. How Revolutionary Were the Bourgeois Revolutions? Chicago, United States: Haymarket Books, 2012. 840 p.

11. Dunford M. Theories of regulation // Environment and Planning D-Society \& Space. 1990. No. 8(3). Pp. 297-321.

12. Dunford M. Chinese economic development and its social and institutional foundations // Dunford M., Liu W.D. The Geographical Transformation of China Preface and acknowledgements. Vol. 133. Abingdon: Routledge, 2014. $372 \mathrm{p}$.

13. Dunford M., Liu W. D. Uneven and combined development // Regional Studies. 2017. No. 51(1). Pp. 69-85.

14. Esping-Andersen G. The Three Worlds of Welfare Capitalism. Cambridge: Polity Press, 1993. 260 p.

15. Frank A.G. ReOrient. Global economy in the Asian age. Berkeley: University of California Press, 1998. 416 p.

16. Gordon R. J. The Rise and Fall of Ameri- can Growth: The U.S. Standard of Living since the Civil War (The Princeton Economic History of the Western World). Princeton, New Jersey: Princeton University Press, 2016. 784 p.

17. Grinin L., Korotayev A. Great Divergence and Great Convergence: a Global Perspective. Switzerland: Springer, 2015. $251 \mathrm{p}$.

18. Grinin L., Korotayev A., Tausch A. Economic Cycles, Crises, and the Global Periphery. Switzerland: Springer, 2016. 265 p.

19. Hall P.A., Soskice D.W. Varieties of Capitalism. The Institutional Foundations of Comparative Advantage. Oxford: Oxford University Press, 2001. 560 p.

20. Hansen A.H. Full recovery or stagnation. New York: Norton, 1938. 350 p.

21. Harootunian H. Marx After Marx: History and Time in the Expansion of Capitalism. New York: Columbia University Press, 2015. 312 p.

22. Harvey D. The new imperialism. Oxford: Oxford University Press, 2003. 288 p.

23. Hobsbawm E. The age of extremes. A history of the world, 1914-1991. London: Michael Jospeh, 1994. 627 p.

24. Hobson J.A. Imperialism, A study. New York: James Pott\&Company, 1902. 412 p.

25. Huntingdon S.P. The Third Wave: Democratization in the Late Twentieth Century. Norman, Oklahoma: University of Oklahoma Press, 1993. 284 p.

26. Jorgenson D.W., Ho M.S., Samuels J.D. Long-term stimates of U.S. productivity and growth. Paper presented at the Third World KLEMS Conference. Growth and Stagnation in the World Economy, Tokyo, 2014. URL: http://www.worldklems.net/ conferences/worldklems2014/worldklems2014_Ho.pdf (дата обращения: 01.10.2017).

27. Kalecki M. Selected essays on the dynamics of the capitalist economy, 193370. Cambridge: Cambridge University Press, 1971. 206 p.

28. Kennedy P. The Rise and Fall of the Great Powers: Economic Change and Military Conflict from 1500 to 2000. New York: Vintage Books, 1987. 704 p.

29. Keynes J.M. The economic consequences 
of Mr. Churchill (1925) // Essays in persuasion. London: Macmillan \& Company, 1931. Pp. 207-230.

30. Keynes J.M. Economic Possibilities for our Grandchildren (1930) // Essays in persuasion. London: Macmillan \& Company, 1931. Pp. 321-332.

31. Keynes J. M. The General Theory of Employment, Interest and Money. London: Macmillan, 1936. 168 p.

32. Kliman A. The failure of capitalist production. Underlying causes of the great recession. London: Pluto Press, 2012. 256 p.

33. Kondratieff N.D. Die langen Wellen der Konjunktur [The long waves of the ecomomy) // Archiv für Sozialwissenschaft und Sozialpolitik. 1926. No. 56(3). Pp. 573-609.

34. Krugman P. Four observations on secular stagnation // Secular stagnation: facts, causes and cures. Ed. by C. Teulings, R. Baldwin. London: CEPR Press, 2014. Pp. 61-68.

35. Lakner C., Milanovic B. Global Income Distribution: From the Fall of the Berlin Wall to the Great Recession // World Bank Economic Review. 2016. No. 30(2). Pp. 203-232.

36. Lin J.Y. The rise of China and its implications for economics and other developing countries //Area Development and Policy. 2017. No. 2(2). Pp. 110-119.

37. Liu W., Dunford M., Song Z., Chen M. Urban-rural integration drives regional economic growth in Chongqing, Western China // Area Development and Policy. 2016. No. 1(1). Pp. 132-154.

38. Matin K. International relations in the making of political Islam: Interrogating khomeini's 'islamic government' // Journal of International Relations and Development. 2013. No. 16(4). Pp.455482.

39. Meade J.E. Efficiency, equality, and the ownership of property. London: Allen \& Unwin, 1964. 92 p.

40. Minsky H.P. Stabilizing an unstable economy. New York: McGraw-Hill, 2008. 350 p.

41. Norfield T. The city. London and the global power of finance. London: Verso, 2016. 288 p.
42. Obstfeld M.,Taylor A.M. Globalization andf capital markets // Globalization in Historical Perspective. Ed. by M. D. Bordo, A. M. a. Taylor, J.G. Williamson. Chicago: University of Chicago Press, 2003. Pp. 121-187.

43. Polanyi K. The Great Transformation: the Political and Economic Origins of Our Time. Boston, MA.: Beacon Press, 1944. 360 p.

44. Quah D. The Global Economy's Shifting Centre of Gravity // Global Policy. 2011. No. 2(1). Pp. 3-9.

45. Rosenberg J. Kenneth Waltz and Leon Trotsky: Anarchy in the mirror of uneven and combined development // International Politics. 2013. No. 50(2). Pp. 183-230.

46. Rosenberg J. Uneven and combined Development: 'The International' in theory and history // Historical Sociology and World History. Uneven and Combined Development over the Longue Durée. Ed. by A. Anievas, K. Matin. London: Rowman \& Littlefield International, 2016. Pp. 17-30.

47. Rosnick D. The Incredible Story of Developing Country Income Growth: Was it Just China? URL: http://cepr.net/ blogs/cepr-blog/the-incredible-storyof-developing-country-income-growthwas-it-just-china (дата обращения: 01.10.2017).

48. Stolper W.F., Samuelson P.A. Protection and real wages // The Review of Economic Studies. 1941. No. 9(1). Pp. 5873.

49. Summers L.H. Reflections on the "new secular stagnation hypothesis // Secular stagnation: facts, causes and cures. Ed. by C. Teulings R. Baldwin. London: CEPR Press, 2014. Pp. 27-38.

50. Tapia Granados J.A. Does Investment Call the Tune? Empirical Evidence and Endogenous Theories of the Business Cycle // Contradictions: Finance, Greed, and Labor Unequally Paid. Ed. by P. Zarembka. Bingley, UK: Emerald Group Publishing Limited, 2013. Pp. 229-259.

51. Trotsky L. The Third International after Lenin. URL: https://www.marxists.org/ archive/trotsky/1928/3rd/index.htm (дата обращения: 01.10.2017). 
52. Trotsky L. The history of the Russian Revolution. URL: https://www.marxists.org/archive/trotsky/1930/hrr/ (дата обращения: 01.10.2017).

53. van der Linden $M$. The 'law' of uneven and combined development: Some underdeveloped thoughts // Historical Materialism-Research in Critical Marx- ist Theory. 2007. No. 15(1). Pp. 145-165.

54. Zhu Y.-H. Gao si zai yun. zhongguo xingqi quanqiu zhixu chongxu [Broad and far-sighted perspectives from the sky. The rise of China and reorganization of the global order]. Beijing: Beijing renmin daxue chubanshe [Beijing Renmin University Press], 2015.

\section{6 aвmopax:}

МайклДанфорд-профессорвотставке,ШколаглобальныхисследованийУниверситета Сассекса; старший научный сотрудник Института географических исследований и изучения природных ресурсов Китайской академии наук, 100101, Пекин, округ Чаоянг, улица Датун, 11A. e-mail: M.F.Dunford@sussex.ac.uk.

Лю Вейдун - профессор экономической географии, заместитель заведующего отдела демографической географии и регионального развития Института географических исследований и изучения природных ресурсов Китайской академии наук, 100101, Пекин, округ Чаоянг, улица Датун, 11A. e-mail: liuwd@igsnrr.ac.cn. 